\title{
SENSIBILITY ANALYSIS OF THE PEARL MODEL FOR PESTICIDE LEACHING IN THE STATE OF MATO GROSSO DO SUL, BRAZIL
}

\author{
RÔMULO P. SCORZA JÚNIOR ${ }^{1}$, JOÃO P. DA SILVA ${ }^{2}$
}

\begin{abstract}
For an accurate use of pesticide leaching models it is necessary to assess the sensitivity of input parameters. The aim of this work was to carry out sensitivity analysis of the pesticide leaching model PEARL for contrasting soil types of Dourados river watershed in the state of Mato Grosso do Sul, Brazil. Sensitivity analysis was done by carrying out many simulations with different input parameters and calculating their influence on the output values. The approach used was called one-at-a-time sensitivity analysis, which consists in varying independently input parameters one at a time and keeping all others constant with the standard scenario. Sensitivity analysis was automated using SESAN tool that was linked to the PEARL model. Results have shown that only soil characteristics influenced the simulated water flux resulting in none variation of this variable for scenarios with different pesticides and same soil. All input parameters that showed the greatest sensitivity with regard to leached pesticide are related to soil and pesticide properties. Sensitivity of all input parameters was scenario dependent, confirming the need of using more than one standard scenario for sensitivity analysis of pesticide leaching models.
\end{abstract}

KEYWORDS: calibration, pesticide leaching model, inverse modeling.

\section{ANÁLISE DE SENSIBILIDADE DO SIMULADOR PEARL PARA LIXIVIAÇÃO DE PESTICIDAS NO ESTADO DE MATO GROSSO DO SUL, BRASIL}

RESUMO: Para o uso confiável de simuladores da lixiviação de pesticidas, é necessária a avaliação da sensibilidade dos dados de entrada. O objetivo deste trabalho foi realizar a análise de sensibilidade do simulador da lixiviação de pesticidas PEARL para tipos de solos contrastantes da Bacia Hidrográfica do Rio Dourados, no Estado de Mato Grosso do Sul, Brasil. A análise de sensibilidade foi feita através da execução de várias simulações com dados de entrada diferentes e calculando suas influências nos resultados obtidos. O método usado foi o denominado de análise de sensibilidade "individual", onde se varia cada dado de entrada de forma independente enquanto se mantêm constantes, os outros dados de entrada, conforme cenário-padrão. A análise de sensibilidade foi automatizada, utilizando-se da ferramenta SESAN, que foi acoplada ao simulador PEARL. Resultados revelaram que somente as características do solo influenciaram nas simulações do fluxo da água e que, para cenários com diferentes pesticidas e mesmo solo, as simulações do fluxo da água não sofreram alterações. Os dados de entrada que mostraram as maiores sensibilidades com relação às simulações da lixiviação de pesticidas estão relacionados às características dos solos e pesticidas. A sensibilidade de todos os dados de entrada estudados foi dependente do tipo de cenário escolhido, confirmando a necessidade de utilizar mais de um cenário-padrão na avaliação da sensibilidade de simuladores da lixiviação de pesticidas.

PALAVRAS-CHAVE: calibração, simulador da lixiviação de pesticidas, modelagem inversa.

\footnotetext{
${ }^{1}$ Researcher, Ph.D., Embrapa Western Region Agriculture, PO BOX 661, Dourados-MS, romulo@cpao.embrapa.br

${ }^{2}$ Undergraduate student of Computer Science at State University of Mato Grosso do Sul, UEMS, Dourados - MS.

Recebido pelo Conselho Editorial em: 11-8-2009

Aprovado pelo Conselho Editorial em: 3-6-2011
} 


\section{INTRODUCTION}

Pesticides used in agriculture can pose contamination risks to groundwater and surface water resources. The entry of pesticides into the groundwater can occur via leaching through the soil profile. Losses of pesticide by leaching can, in some exceptional cases be as high as 5\%, but are normally less than 1\% (CARTER, 2000). There is an urgent need to assess the risks of groundwater contamination by pesticides. However, this assessment at field scale for all combinations of pesticides, soil and climate conditions are time- and money consuming (BOESTEN, 2000). To overcome this limitation, mathematical models have been created to simulate pesticide leaching considering all diversity of climate conditions, soils and pesticides. Thus, the use of Pesticide Leaching Models (PLM) for risk assessment can result in economy of time and financial resources. One of these PLM is the PEARL model (BOESTEN, 2007), which has been used for pesticide risk assessment within the European Union. For an accurate use of PLM it is necessary to assess the sensitivity of input parameters. This sensitivity has been evaluated by sensitivity analysis, which has the aim to identify the relationship between model inputs and outputs (VANDERBORGHT et al., 2011; HEUVELINK et al., 2010). One important use of sensitivity analysis is to identify which are the most important parameters in a model. On the other way, sensitivity analysis can identify the least relevant parameters and suggest model refinement or simplification. Moreover, sensitivity analysis can help in the selection of parameters for model calibration and probabilistic modeling. Results of sensitivity analysis have shown to be scenario dependent (VANDERBORGHT et al., 2011). Therefore, conclusions about sensitivity analysis in one scenario (e.g. soil type or climate conditions) may not be directly applied to the other. So there is a need to carry out sensitivity analysis for different scenarios. Studies that show the sensitivity analysis of PLM under Brazilian scenarios are scarce. The aim of this study was to carry out sensitivity analysis of the PEARL model for contrasting soil types using data of Dourados river watershed in the state of Mato Grosso do Sul, Brazil.

\section{MATERIAL AND METHODS}

The PEARL model used for sensitivity analysis was version 3.3.3 (BOESTEN, 2007). PEARL uses the SWAP model (VAN DAM et al., 2008; SCORZA JÚNIOR et al., 2010) to describe soil water flow using Richards's equation and considering a one-dimensional, vertical and transient flow. Soil temperature is simulated using the combination of Fourier's law and the conservation equation for heat in soil. The relationship between soil water content and its pressure head is described by the Van Genuchten model and the hydraulic conductivity by the Mualem model (VAN GENUCHTEN, 1980). In PEARL, the mass conservation equation of pesticide in soil is given by:

$$
\frac{\partial C^{*}}{\partial t}=\frac{\partial}{\partial z}\left(q \cdot C_{L}-D_{L} \frac{\partial C_{L}}{\partial z}-D_{G} \frac{\partial C_{G}}{\partial z}\right)-R_{T}-R_{U}
$$

where,

$\mathrm{C}^{*}$ - the total concentration of pesticide in soil, $\mathrm{g} \mathrm{cm}^{-3}$;

$\mathrm{t}$ - time, day;

$\mathrm{z}$ - depth, cm;

$\mathrm{q}$ - volume flux of water in soil, $\mathrm{cm} \mathrm{day}^{-1}$;

$\mathrm{C}_{\mathrm{L}}$ - concentration of pesticide in the liquid phase, $\mathrm{g} \mathrm{cm}^{-3}$;

$\mathrm{D}_{\mathrm{L}}$ - hydrodynamic dispersion coefficient, $\mathrm{cm}^{2}$ day $^{-1}$;

$\mathrm{D}_{\mathrm{G}}$ - gas diffusion coefficient, $\mathrm{cm}^{2}$ day $^{-1}$;

$\mathrm{C}_{\mathrm{G}}$ - concentration of pesticide in the gas phase, $\mathrm{g} \mathrm{cm}^{-3}$;

$\mathrm{R}_{\mathrm{T}}$ - transformation rate of pesticides in soil, $\mathrm{g} \mathrm{cm}^{-3} \mathrm{day}^{-1}$, and

$\mathrm{R}_{\mathrm{U}}$ - pesticide uptake by plants, $\mathrm{g} \mathrm{cm}^{-3}$ day $^{-1}$. 
Pesticide sorption is described with the Freundlich isotherm. The transformation rate of pesticides in soil is described by a first-order equation. Input data for PEARL were obtained in the literature and in-situ measurements.

The following 18 PEARL input parameters were evaluated during sensitivity analysis: reference temperature of half-life (TR), half-life (HL), organic-matter content (OM), organic-matter partition coefficient $\left(\mathrm{K}_{\mathrm{OM}}\right)$, saturated water content (TSAT), van Genuchten parameters (N and ALPHA), dispersion length (DL), residual water content (TRES), dry soil bulk density (DENS), Freundlich sorption exponent (FE), molar enthalpy of sorption (MS), crop factor (CF), parameter in soil evaporation reduction equation (SE), molar activation energy (ME), saturated hydraulic conductivity (KSAT), exponent for the effect of soil moisture content on degradation (EL), and coefficient for uptake by plant (UP).

Meteorological data (daily precipitation, daily maximum and minimum air temperatures, air velocity at $2 \mathrm{~m}$ height, relative air humidity and sun hours per day) were obtained from a time-series of 27 years from 01 January 1980 until 31 December 2006 in an automated meteorological station located at Embrapa Western Region Agriculture, in Dourados, Mato Grosso do Sul. For all scenarios and during the 27 years of simulation, it was considered the cultivation of two crops every year being soybean in summer (planting date on November $5^{\text {th }}$ and harvest on March $1^{\text {st }}$ ) and corn in autumn-winter (planting date on March $10^{\text {th }}$ and harvest on June10 ${ }^{\text {th }}$ ). For both crops the input parameters were obtained from SCORZA JÚNIOR \& SILVA (2006).

Sensitivity analysis was done by carrying out many simulations with different input parameters and calculating their influence on the output values. The approach used was the one called one-at-a-time sensitivity analysis (DUBUS et al., 2003). It consists in varying independently input parameters one at a time and keeping all others constant with the standard scenario values. Thus, it is possible to assess the sensitivity of each input parameter by observing the influence on model outputs. Sensitivity analysis was automated using SENSAN tool that is part of the inverse modeling PEST package (DOHERTY, 2000). This tool is linked to PEARL model using input and output files. SENSAN uses a template file to create PEARL input files. Thereafter, SENSAN runs simulations to obtain output files and carry out sensitivity analysis. SENSAN interferes in PEARL using its input and output files only and thus it is fully modeled independent. Variation in the output values was always calculated in relation to a pre-established standard scenario. Six different standard scenarios were used as a combination of three soil types $(0-100 \mathrm{~cm} \mathrm{depth})$ and two pesticides. The following three contrasting soil types from Dourados river watershed were used: a very clay typical distroferric Red Latossol (LVdf), a dystrophic Red Latossol (LVd) and a dystrophic Red Argisol (PV) (SANTOS et al., 2006). These soil types are predominant in Dourados river watershed that has about $74.6 \%$ of LVdf, $23.2 \%$ of LVd, and $1.8 \%$ of PV (OLIVEIRA et al., 2000). Soil samples were collected at 0-10, 10-20, 20-40, 40-60, and 60-100 cm depth for chemical and soil physical determinations (CLAESSEN, 1997) in the municipalities of Dourados $\left(22^{\circ} 16^{\prime}\right.$

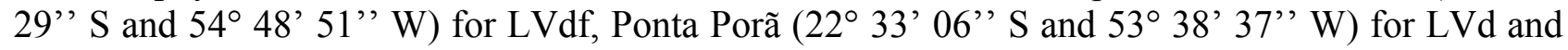
Deodápolis $\left(22^{\circ} 14^{\prime} 46^{\prime}, \mathrm{S}\right.$ and $54^{\circ} 09^{\prime} 22^{\prime}$ ' $\left.\mathrm{W}\right)$ for PV (Table 1$)$. In-situ measurements were carried out for saturated hydraulic conductivities using a Guelph permeameter. Soil water retention data were fitted to van Genuchten model using RETC package (VAN GENUCHTEN et al., 1991) and parameters are shown in Table 2. Two hypothetical pesticides with contrasting field behavior were selected. $\mathrm{K}_{\mathrm{OM}}$ and $\mathrm{DT}_{50}$ were, respectively, $10 \mathrm{~L} \mathrm{~kg}^{-1}$ and 20 days for pesticide 1 and $120 \mathrm{~L} \mathrm{~kg}^{-1}$ and 80 days for pesticide 2 . These parameters indicate that pesticide 1 is very mobile and has a short half-live and pesticide 2 has moderate mobility and half-life. The output variables in PEARL used for calculation of sensitivity analysis were cumulative flux of water percolated at $1 \mathrm{~m}$ depth $(\mathrm{m})$ and cumulative areic mass of leached pesticide at $1 \mathrm{~m}$ depth $\left(\mathrm{kg} \mathrm{ha}^{-1}\right)$. 
TABLE 1. Physico-chemical properties for the three predominant soils in Dourados river watershed, state of Mato Grosso do Sul, Brazil.

\begin{tabular}{ccccccc}
\hline \multirow{2}{*}{ Depth $(\mathrm{cm})$} & \multicolumn{7}{c}{$\mathrm{LVdf}$ Soil } \\
\cline { 2 - 7 } $\mathrm{OM}\left(\mathrm{g} \mathrm{kg}^{-1}\right)$ & Sand $\left(\mathrm{g} \mathrm{kg}^{-1}\right)$ & Clay $\left(\mathrm{g} \mathrm{kg}^{-1}\right)$ & $\mathrm{pH}-\mathrm{CaCl}_{2}$ & $\mathrm{BD}\left(\mathrm{g} \mathrm{cm}^{-3}\right)$ & $\mathrm{MAP}(\%)$ \\
\hline $0-10$ & 33.4 & 245 & 630 & 4.8 & 1.020 & 34.95 \\
$10-20$ & 29.6 & 229 & 663 & 4.4 & 1.114 & 28.45 \\
$20-40$ & 22.7 & 212 & 697 & 4.5 & 1.136 & 26.52 \\
$40-60$ & 16.9 & 195 & 713 & 4.6 & 1.113 & 21.53 \\
$60-100$ & 11.3 & 195 & 713 & 4.6 & 1.104 & 19.31 \\
\hline \multirow{7}{*}{ Depth $(\mathrm{cm})$} & $\mathrm{OM}\left(\mathrm{g} \mathrm{kg}^{-1}\right)$ & Sand $\left(\mathrm{g} \mathrm{kg}^{-1}\right)$ & Clay $\left(\mathrm{g} \mathrm{kg}^{-1}\right)$ & $\mathrm{pH}-\mathrm{CaCl}_{2}$ & $\mathrm{BD}\left(\mathrm{g} \mathrm{cm}^{-3}\right)$ & $\mathrm{MAP}(\%)$ \\
\hline $0-10$ & 17.5 & 743 & 213 & 4.9 & 1.419 & 15.02 \\
$10-20$ & 16.5 & 743 & 230 & 4.9 & 1.509 & 12.66 \\
$20-40$ & 13.8 & 726 & 230 & 4.3 & 1.486 & 14.88 \\
$40-60$ & 11.0 & 710 & 247 & 4.2 & 1.461 & 16.01 \\
$60-100$ & 6.9 & 693 & 263 & 4.1 & 1.411 & 17.54 \\
\hline \multirow{2}{*}{ Depth $(\mathrm{cm})$} & $\mathrm{OM}\left(\mathrm{g} \mathrm{kg}^{-1}\right)$ & Sand $\left(\mathrm{g} \mathrm{kg}^{-1}\right)$ & Clay $\left(\mathrm{g} \mathrm{kg}^{-1}\right)$ & $\mathrm{pH}-\mathrm{CaCl}_{2}$ & $\mathrm{BD}\left(\mathrm{g} \mathrm{cm}^{-3}\right)$ & $\mathrm{MAP}(\%)$ \\
\hline $0-10$ & 7.4 & 888 & 80 & 4.1 & 1.359 & 26.50 \\
$10-20$ & 6.4 & 869 & 97 & 4.0 & 1.546 & 22.16 \\
$20-40$ & 5.1 & 852 & 111 & 4.0 & 1.532 & 23.20 \\
$40-60$ & 4.7 & 869 & 97 & 4.1 & 1.510 & 26.06 \\
$60-100$ & 5.4 & 888 & 97 & 4.1 & 1.466 & 27.06 \\
\hline
\end{tabular}

OM - organic-matter content; BD - dry soil bulk density; MAP - soil macroporosity.

Sensitivity of each input parameter for an individual scenario was assessed using the ratio of variation (ROV) given by the relationship between output and input variation. For each simulation, ROV was calculated based on five different input values. The sensitivity of the input value was represented by the maximum absolute ratio of variation (MAROV) given by (DUBUS et al., 2003):

$$
M A R O V=\max \left|\frac{o-o_{S S}}{I-I_{S S}} \cdot \frac{I_{S S}}{o_{S S}}\right|
$$

where,

O - output variable value;

$\mathrm{O}_{\mathrm{SS}}$ - output variable value for the standard scenario;

I - input parameter value, and

$\mathrm{I}_{\mathrm{SS}}$-input parameter value for the standard scenario.

As a rule, the larger the MAROV value, the more influence a parameter has on model output. For example, if MAROV equals to 10, the disturbance of model input will be propagated through the model and amplified to result in a maximum variation of the output by 10 times more.

\section{RESULTS AND DISCUSSION}

Cumulative values of water flux percolated at $1 \mathrm{~m}$ depth (CWF) for the simulated period of 27 years (between 1980 and 2006) for all six standard scenarios did vary between 19.01 and $27.11 \mathrm{~m}$ (Table 3). The sandy soil PV did show the greatest amount of CWF $(27.11 \mathrm{~m})$ as could be expected by its physic and hydraulic characteristics (i.e. low clay contents within the soil profile and therefore low water retention together with high $\mathrm{K}_{\mathrm{s}}$ values) (Tables 1,2 and 3). These simulated CWF values correspond to about $68.7 \%$ of the total cumulative precipitation for PV soil, $48.2 \%$ for LVdf soil, and $1.5 \%$ for LVd soil. As expected, only soil characteristics influence CWF and therefore no variation was observed of this value for the same soil and different pesticides (Table 3). As the initial amount applied for both pesticides was $100 \mathrm{~kg} \mathrm{ha}^{-1}$, these MLP values correspond to the range of 0.09 and $6.47 \%$ of the total amount applied. These amounts are close to a realistic situation (between 1 and 5\%) that is expected in the field (CARTER, 2000; BROWN \& VAN 
BEINUM, 2009). Thus, the six standard scenarios used in this study can be considered relevant within the context of using pesticide leaching model to mimic a real situation.

TABLE 2. Residual volumetric water content $\left(\theta_{\mathrm{r}}\right)$, saturated volumetric water content $\left(\theta_{\mathrm{s}}\right)$, Van Genuchten parameters $\alpha, \mathrm{n}$, and $\lambda$ and saturated hydraulic conductivity $\left(\mathrm{K}_{\mathrm{s}}\right)$ for the three predominant soils in Dourados river watershed, state of Mato Grosso do Sul, Brazil.

\begin{tabular}{ccccccc}
\hline \multirow{2}{*}{ Depth $(\mathrm{cm})$} & \multicolumn{7}{c}{ LVdf Soil } \\
\cline { 2 - 7 } & $\theta_{\mathrm{r}}\left(\mathrm{cm}^{3} \mathrm{~cm}^{-3}\right)$ & $\theta_{\mathrm{s}}\left(\mathrm{cm}^{3} \mathrm{~cm}^{-3}\right)$ & $\alpha\left(\mathrm{cm}^{-1}\right)$ & $\mathrm{n}(-)$ & $\lambda(-)$ & $\mathrm{K}_{\mathrm{s}}\left(\mathrm{m} \mathrm{day}^{-1}\right)$ \\
\hline $0-10$ & 0.2199 & 0.6140 & 0.0805 & 2.0 & 0.5 & 7.34 \\
$10-20$ & 0.2336 & 0.5830 & 0.0635 & 1.8 & 0.5 & 3.64 \\
$20-40$ & 0.2343 & 0.5880 & 0.0589 & 1.7 & 0.5 & 2.77 \\
$40-60$ & 0.2433 & 0.5680 & 0.0445 & 1.7 & 0.5 & 2.27 \\
$60-100$ & 0.2509 & 0.5670 & 0.0268 & 2.0 & 0.5 & 1.21 \\
\hline \multirow{2}{*}{ Depth $(\mathrm{cm})$} & $\theta_{\mathrm{r}}\left(\mathrm{cm}^{3} \mathrm{~cm}^{-3}\right)$ & $\theta_{\mathrm{s}}\left(\mathrm{cm}^{3} \mathrm{~cm}^{-3}\right)$ & $\alpha\left(\mathrm{cm}^{-1}\right)$ & $\mathrm{n}(-)$ & $\lambda(-)$ & $\mathrm{K}_{\mathrm{s}}\left(\mathrm{m} \mathrm{day}^{-1}\right)$ \\
\hline $0-10$ & 0.1605 & 0.4205 & 0.0146 & 2.5 & 0.5 & 0.49 \\
$10-20$ & 0.1728 & 0.3906 & 0.0120 & 2.9 & 0.5 & 0.80 \\
$20-40$ & 0.1632 & 0.4071 & 0.0138 & 2.5 & 0.5 & 1.08 \\
$40-60$ & 0.1533 & 0.4118 & 0.0149 & 2.5 & 0.5 & 2.95 \\
$60-100$ & 0.1525 & 0.4244 & 0.0153 & 3.0 & 0.5 & 3.73 \\
\hline \multirow{2}{*}{ Depth $(\mathrm{cm})$} & $\theta_{\mathrm{r}}\left(\mathrm{cm}^{3} \mathrm{~cm}^{-3}\right)$ & $\theta_{\mathrm{s}}\left(\mathrm{cm}^{3} \mathrm{~cm}^{-3}\right)$ & $\alpha\left(\mathrm{cm}^{-1}\right)$ & $\mathrm{n}(-)$ & $\lambda(-)$ & $\mathrm{K}_{\mathrm{s}}\left(\mathrm{m} \mathrm{day}^{-1}\right)$ \\
\hline $0-10$ & 0.0592 & 0.3907 & 0.0302 & 2.5 & 0.5 & 3.75 \\
$10-20$ & 0.0796 & 0.3802 & 0.0183 & 3.2 & 0.5 & 1.63 \\
$20-40$ & 0.0937 & 0.3954 & 0.0186 & 3.2 & 0.5 & 0.80 \\
$40-60$ & 0.0746 & 0.3918 & 0.0229 & 3.0 & 0.5 & 6.98 \\
$60-100$ & 0.0731 & 0.4007 & 0.0239 & 3.0 & 0.5 & 5.77 \\
\hline
\end{tabular}

The greatest MLP values were for PV soil indicating more pesticide leaching for this soil when compared to the other two (Table 3). This more pronounced leaching for PV soil is, in part, a consequence of more water flow as demonstrated by CWF values and also because water fluxes are important processes for pesticide leaching. Both soil and pesticide characteristics did influence pesticide leaching as shown by different MLP values for all six standard scenarios. For LVdf and LVd soils, the values of MLP for pesticide 2 were greater than for pesticide 1 . However, for PV soil, the opposite occurred being MLP value greater for pesticide 1 than for pesticide 2 . Considering that pesticide 1 is more mobile ( $\mathrm{K}_{\mathrm{OM}}$ equal to $10 \mathrm{~L} \mathrm{~kg}^{-1}$ ) than pesticide $2\left(\mathrm{~K}_{\mathrm{OM}}\right.$ equal to $120 \mathrm{~L} \mathrm{~kg}^{-1}$ ), it was expected that MLP values would be greater for pesticide 1 than for pesticide 2 for all scenarios. It only happened for scenarios with PV soil that had more water flow. It means that not only $\mathrm{K}_{\mathrm{OM}}$ can be used to inquire about pesticide leaching for all six standard scenarios.

TABLE 3. Simulated cumulative values of water flux percolated at $1 \mathrm{~m}$ depth (CWF) and areic mass of leached pesticide at $1 \mathrm{~m}$ depth (MLP) for six scenarios at Dourados river watershed, state of Mato Grosso do Sul, Brazil.

\begin{tabular}{cccc}
\hline \multirow{2}{*}{ Soil } & \multirow{2}{*}{ Pesticide } & \multicolumn{2}{c}{ Cumulative values } \\
\cline { 3 - 4 } & 1 & 19.01 & MLP $\left(\mathrm{kg} \mathrm{ha}^{-1}\right)$ \\
\hline \multirow{2}{*}{ LVdf } & 2 & 19.01 & 0.09 \\
& 1 & 21.30 & 0.26 \\
\hline \multirow{2}{*}{ LVd } & 2 & 21.30 & 0.33 \\
& 1 & 27.11 & 1.15 \\
\hline \multirow{2}{*}{ PV } & 2 & 27.11 & 6.47 \\
& & & 5.08 \\
\hline
\end{tabular}


Processes of pesticide dissipation in soil were influenced by soil and pesticide type (Figure 1). For all standard scenarios, degradation was the main process responsible for 65 to $95 \%$ of the total pesticide dissipation. Uptake of pesticide by root was between 12 and $26 \%$ for pesticide 1 and between 4 and $16 \%$ for pesticide 2 considering all soil types. The greater root uptake of pesticide 1 than pesticide 2 can be explained by its lower $\mathrm{K}_{\mathrm{OM}}$ value that leads to more pesticide in soil liquid phase and hence more pesticide available for root uptake. In general, for PV soil, pesticide uptake by root was more pronounced when compared to LVdf and LVd soil types.

Results from sensitivity analysis for MLP show that the most sensitivity input parameters (i.e. MAROV > 10) were TR, HL, OM, $\mathrm{K}_{\mathrm{OM}}, \mathrm{FE}$ and DENS (Figure 2). All input parameters that showed the greatest sensitivity are related to soil and pesticide properties. More specifically, most of these parameters are related to sorption and degradation (i.e. TR, HL, OM, $\mathrm{K}_{\mathrm{OM}}$ and FE). DUBUS et al. (2003) also found that for simulation of pesticide leaching the most sensitive input parameters were the ones related to sorption and degradation processes. Usually, degradation and sorption input parameters are determined in the laboratory and have been directly applied to simulate field behavior of pesticides using PLM. However, this straightforward use has generated much debate because sorption and degradation parameters can be variable in space and time (WALKER et al., 2001) and thus can introduce much uncertainty in PEARL given its considerable sensibility to these parameters as shown in this study. The sensitivity of DENS was relevant because this parameter has a great influence in the partition of pesticide between the solid and liquid phase. Input parameters related to soil water flow and crop properties (e.g. TRES and CF) did show low sensitivity for MLP. For example, MAROV value for TR considering LVdf soil and pesticide 1 was 51. This value means that if we vary TR in one unit, it can modify MLP as much as 51 times. MAROV values equal to or lower than one mean that these parameters are less sensitive and they can modify outputs in the same variation of input value for MAROV equal to one or less for MAROV less than one.

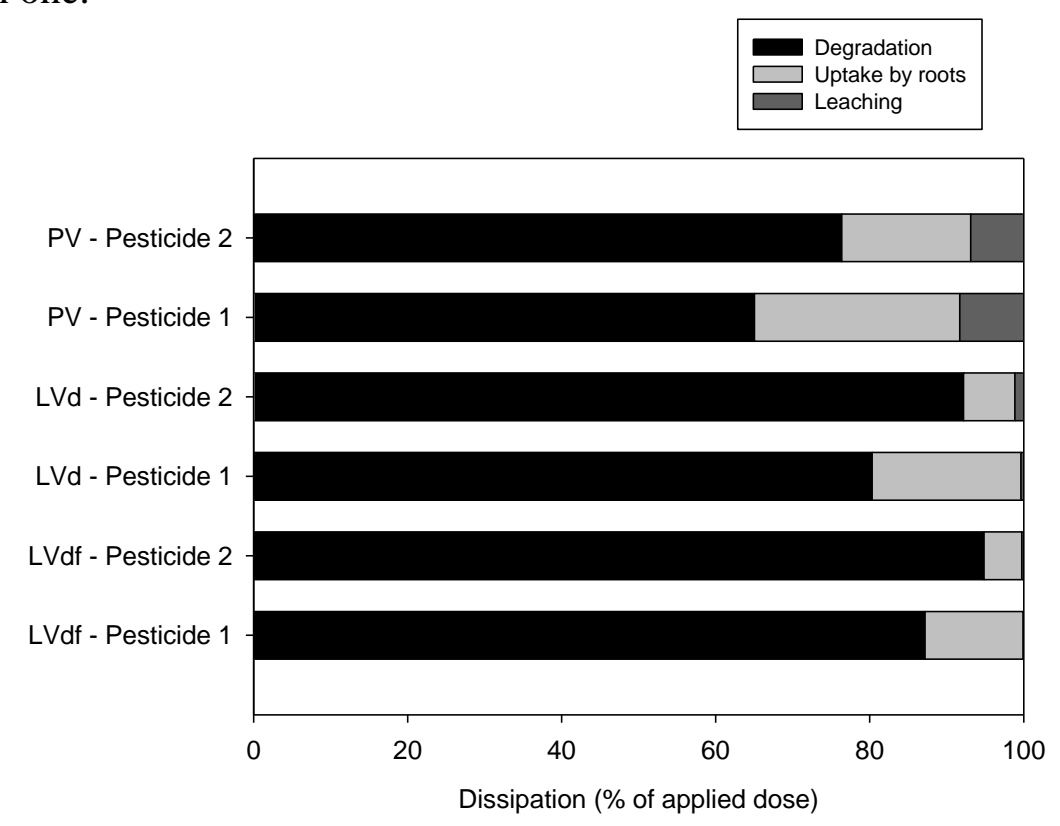

FIGURE 1. Main processes of pesticides dissipation in soil for all six standard scenarios.

Sensitivity of input parameters varied as a function of different scenarios characteristics. The greatest variations in MAROV values were observed for scenarios with LVdf soil (Figure 2). On the other way, the smallest variations in MAROV values were observed for scenarios with PV soil. Some input parameters did show strong influence (i.e. MAROV values greater or closer to 10) in MLP for almost all scenarios as for example TR and OM. It is important to point out that sensitivity of PEARL to OM input parameter was more pronounced for pesticide 2 than for pesticide 1 considering LVdf and LVd soils (Figure 2). The reason for this is because the amount of pesticide 
sorbed on the solid phase is proportional to $\mathrm{OM}$ and $\mathrm{K}_{\mathrm{OM}}$. Therefore, it is expected that $\mathrm{OM}$ in soil will have strong influence on the amount leached for pesticides with high $\mathrm{K}_{\mathrm{OM}}$ values. However, not only the amount of $\mathrm{OM}$ is important for pesticide leaching but also its nature (i.e. bonding mechanisms and its intensity can be largely depended on the OM nature). In a recent work, LIMA et al. (2010) concluded that potential risks of the herbicide atrazina to the environment should not only be based on the OM content itself but also on its nature. Because of that, the use of PLM for risk assessment should consider, in the near future, more complex models to describe pesticide sorption that can deal with the influence of OM nature. Other input parameters did show less influence (i.e. MAROV lower or closer to 1) for almost all scenarios being UP, KSAT, SE, and EL as examples.

In general, sensitivity of PEARL input parameters was scenario-dependent. This confirms the importance of using more than one standard scenario to evaluate the sensitivity of pesticide leaching model. Important to mention that the magnitude of the sensitivities was scenario-dependent and was smallest for scenario where the greatest leaching of pesticides were predicted (i.e. PV soil) and the greatest for scenario where the smallest leaching were predicted (i.e. LVdf and LV soils). This implies that a special attention should be paid in situations when PLM have been used to predict very small pesticide concentrations in water resources.
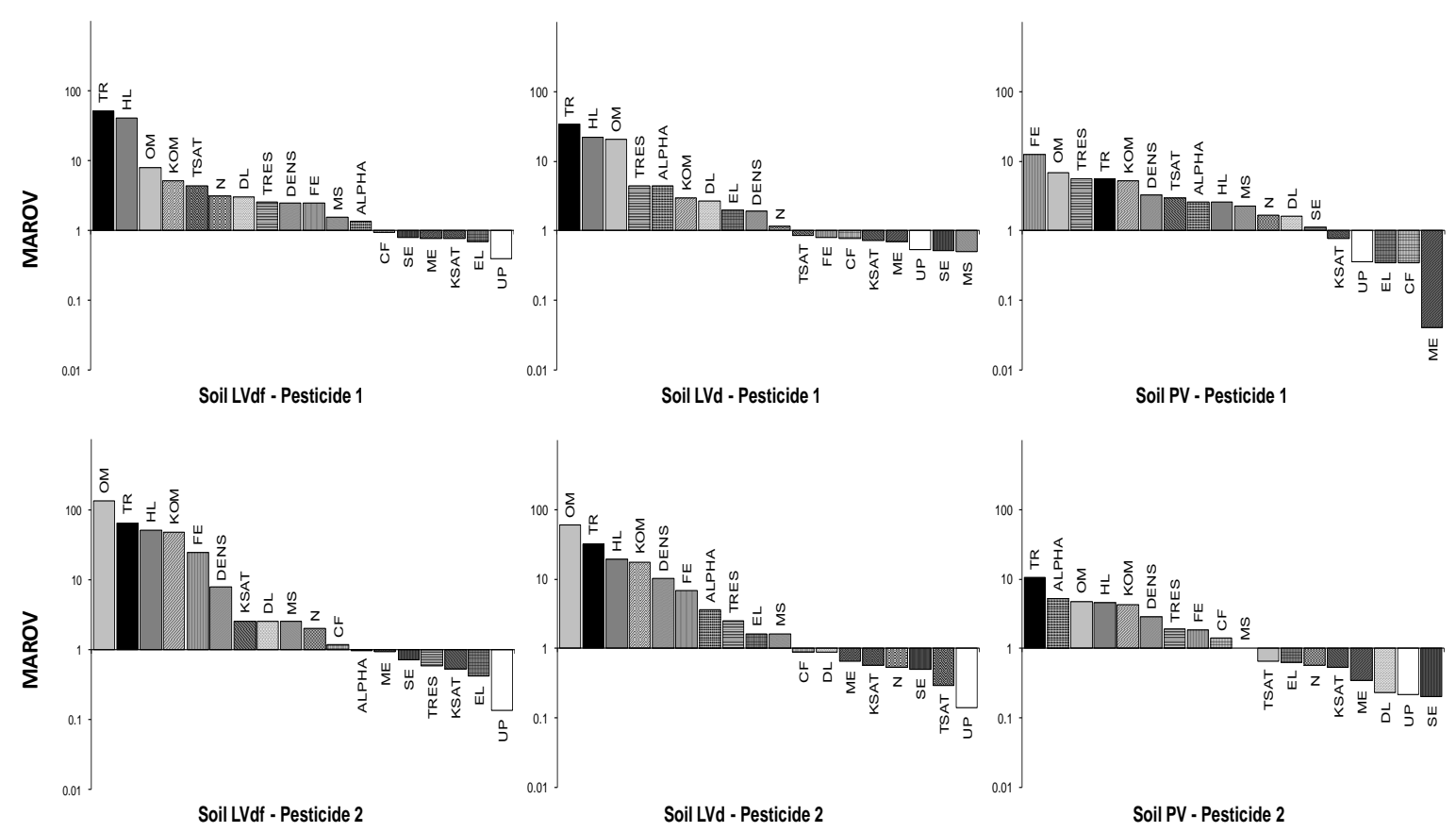

FIGURE 2. MAROV values for all six scenarios considering areic mass of leached pesticide at $1 \mathrm{~m}$ depth as the output. TR - Reference temperature of half-life; HL - half-life; OM organic-matter content; KOM - organic-matter partition coefficient; TSAT - saturated water content; N and ALPHA - Van Genuchten parameters; DL - dispersion length; TRES - residual water content; DENS - dry soil bulk density; FE - Freundlich sorption exponent; MS - molar enthalpy of sorption; CF - crop factor; SE - parameter in soil evaporation reduction equation; ME - molar activation energy; KSAT saturated hydraulic conductivity; EL - exponent for the effect of soil moisture content on degradation; UP - coefficient for uptake by plant.

\section{CONCLUSIONS}

The most sensitivity input parameters for simulation of pesticide leaching using PEARL and for all considered scenarios were related to degradation and sorption and the ones related to soil water flow and crop properties did show low sensitivity. Sensitivity analysis of the PEARL model 
was scenario-dependent under Brazilian conditions. This suggests that before any application of this model for risk assessment in Brazil it is necessary to know sensitivity of the input parameters based on the scenarios it will be applied.

\section{ACKNOWLEDGMENTS}

We appreciate the support of the National Council for Scientific and Technological Development (CNPq) in Brazil for second author scholarship (PIBIC/CNPq). We thank anonymous reviewers for useful critical comments and suggestions.

\section{REFERENCES}

BOESTEN, J.J.T.I. From laboratory to field: uses and limitations of pesticide behavior models for the soil/plant system. Weed Research, Oxford, v.40, p.123-138, 2000.

BOESTEN, J.J.T.I. Simulation of pesticide leaching in the field and in zero-tension lysimeters. Vadose Zone Journal, Madison, v.6, n.4, p.793-804, 2007.

BROWN, C.D.; VAN BEINUM, W. Pesticide transport via sub-surface drains in Europe. Environmental Pollution, Amsterdam, v.157, p.3314-3324, 2009.

CARTER, A.D. Herbicide movement in soils: principles, pathways and processes. Weed Research, Oxford, v.40, p.113-122, 2000.

CLAESSEN, M.E.C. (Org.) Manual de métodos de análise de solo. 2. ed. rev. atual. Rio de Janeiro: Embrapa-CNPS, 1997. 212 p. (Documentos, 1).

DOHERTY, J. Visual PEST (user's manual). Corinda: Watermark Numerical Computing, 2000.

DUBUS, I.G.; BROWN, C.D.; BEULKE, S. Sensitivity analyses for four pesticide leaching models. Pest and Management Science, West Sussex, v.59, p.962-982, 2003.

HEUVELINK, G.B.M.; BURGERS, S.L.G.E.; TIKTAK, A.; VAN DEN BERG, F. Uncertainty and stochastic sensitivity analysis of the GeoPEARL pesticide leaching model, Geoderma, Amsterdam, v.155, p.186-192, 2010.

LIMA, D.L.D.; SCHNEIDER, R.J.; SCHERER, H.W.; DUARTE, A.C.; SANTOS, E.B.H.; ESTEVES, V.I. Sorption-Desorption behavior of atrazine on soils subjected to different organic long-term amendments. Journal of Agricultural and Food Chemistry, Washington, v.58, p.31013106, 2010.

OLIVEIRA, H.; URCHEI, M.A.; FIETZ, C.R. Aspectos físicos e socioeconômicos da Bacia Hidrográfica do Rio Ivinhema. Dourados: Embrapa Agropecuária Oeste, 2000. 52 p. (Documentos, 25).

SANTOS, H.G.; JACOMINE, P.K.T.; ANJOS, L.H.C.; OLIVEIRA, V.A.; OLIVEIRA, J.B.; COELHO, M.R.; LUMBRERAS, J.F.; CUNHA, T.J.F. (Ed.). Sistema brasileiro de classificação de solos. 2. Ed. Rio de Janeiro: Embrapa Solos, 2006. 306 p.

SCORZA JÚNIOR, R.P.; SILVA, J.P. Avaliação do potencial de contaminação dos recursos hídricos por pesticidas na Bacia do Rio Dourados, MS. Dourados: Embrapa Agropecuária Oeste, 2006. 59 p. (Boletim de pesquisa e desenvolvimento, 36).

SCORZA JÚNIOR, R.P.; SILVA, J.P.; RIGITANO, R.L.O. Simulation of moisture profiles in a Latossol in Dourados Region, in the State of Mato Grosso do Sul, Brazil. Engenharia Agrícola, Jaboticabal, v.30, n.1, p.22-32, 2010.

VAN DAM, J.C.; GROENENDIJK, P.; HENDRIKS, R.F.A.; KROES, J.G. Advances of modeling water flow in variably saturated soils with SWAP. Vadose Zone Journal, Madison, v.7, p.640-653, 2008. 
VAN GENUCHTEN, M.Th. A closed-form equation for predicting the hydraulic conductivity of unsaturated soils. Soil Science Society of America Journal, Madison, v.44, p.892-898, 1980.

VAN GENUCHTEN, M.Th.; LEIJ, F.J.; YATES, S.R. The RETC code for quantifying the hydraulic functions of unsaturated soils. Riverside: US Salinity Laboratory, 1991. 93p.

VANDERBORGHT, J.; TIKTAK, A.; BOESTEN, J.T.I. BOESTEN; VEREECKEN, H. Effect of pesticide fate parameters and their uncertainty on the selection of "worst-case" scenarios of pesticide leaching to groundwater. Pest Management Science, West Sussex, v.67, p.294-306, 2011.

WALKER, A.; JURADO-EXPOSITO, M.; BENDING, G.D.; SMITH, V.J.R. Spatial variability in the degradation rate of isoproturon in soil. Environmental Pollution, Amsterdam, v.111, p.407-415, 2001. 